\title{
Sustainable Democracy, Development and Environmental Policies
}

\section{Commonwealth Journal of Local Governance \\ Issue 8/9: May-November 2011 \\ http://epress.lib.uts.edu.au/ojs/index.php/cjlg}

\section{Guest Editors:}

\section{Steve Martin}

Centre for Local \& Regional Government Research

Cardiff Business School, Cardiff University

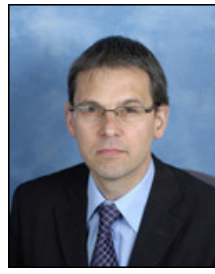

\section{Alison Brown \\ School of City and Regional Planning \\ Cardiff University}

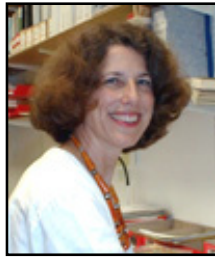

Urbanisation, climate change, footloose economies, multi-culturality and resource constraints pose unprecedented challenges for local governments today. In the developing world the gulf between needs and finance remains acute. Many western countries forced to reduce public spending in the wake of the sovereign debt crisis, are struggling to reconcile the need for efficiency savings with local pressure to maintain service standards and working conditions. This special double issue of the journal features a selection of papers presented at the third Commonwealth Local Government Research Colloquium held in Cardiff on 13-15 March 2011 which explored these and other important contemporary challenges. Hosted by the School of City and Regional Planning and the Centre for Local and Regional Government Research at Cardiff University, the colloquium provided a valuable opportunity for scholars from across the Commonwealth to present research on three key themes: sustainable democracy and governance, sustainable economic development and environmental sustainability.

In his welcoming address Professor Chris Webster highlighted the way in which the shifting boundaries of local governance are presenting new challenges for researchers. Privately managed neighbourhoods which bypass traditional local government services are now commonplace. Relations between central and local government are increasingly 
fluid as imbalances in resources between rich city governments and poorer neighbouring authorities become more acute. Developments such as the adoption of new financing models (including the use of government bonds) and innovative approaches to service delivery are forcing researchers, policy makers and practitioners to think again about the role of local governments. Following this introduction, Professor P. S. Reddy presented the key themes from the insightful background paper that he was commissioned to prepare for the CLGF conference which followed the research colloquium. The paper explored the opportunities and challenges for local government as it seeks to promote local economic development and can be accessed at http://www.clgc2011.org/clgc2011background-paper.

The contributions to this special issue reflect all three of the colloquium's themes. The first four research papers focus on sustainable democracy and governance. Robin Hambleton explores the concept of placed-based leadership which he argues deserves more attention from scholars and practitioners. Robin identifies three realms of civic leadership: political leadership which derives its legitimacy from the ballot box; professional leadership exercised by paid officials, and community leadership provided by activists, business people and volunteers. Applying this model to the development of Freiberg in Germany as a successful 'eco-city', Robin suggests that inspirational civic leadership can facilitate innovation and strengthen local democratic accountability.

In a fascinating analysis of the Panchayati Raj of West Bengal, Bhaskar Chakrabarti, Raghabendra Chattpadhyay and Suman Nath analyse the decentralisation of 15 state departments' functions to district and block level governments in 2005. The move followed the 1992 73rd Amendment of the Indian Constitution, which sought to enable the Panchayat to function as effective institutions of self-government. They map activities in the restructured government system, including capacity-building, financial assistance, budgeting, co-ordination and monitoring. Their analysis highlights a range of problems including inadequate coordination, the lack of a mandate for effective collaboration, and role confusion and power struggles amongst officials and members. The authors argue that there is an urgent need to redefine respective roles and enhance collaboration.

Stephen Greasley's paper examines the effectiveness and stability of cabinet-style local government which was introduced in the UK in 2000. To date little research has 
explored the role of cabinet members, who play a crucial role in policy development. Stephen's research painstakingly analysed cabinet and committee reports from 114 councils, tracking electoral change and the movement of cabinet members from 2004/05 to 2009/10. He reports that there have been significant differences in cabinet turnover, with relative stability in the three mayoral authorities. Stephen concludes that stabile leadership is crucial for effective democracy in cabinet-style government.

Steve Martin tracks the recent history of performance evaluation in local government in the UK. Top-down performance regimes imposed by the centre-left Labour government between 1997 and 2010 were seen by their critics as wrong in principle and costly to implement. However, the evidence suggests that they contributed to significant improvements in local government performance. A Localism Bill introduced by a new Coalition government in 2010 promises to sweep away external assessment of local authorities. Steve argues that only time will tell whether this represents a genuine attempt to devolve power to local government or is simply a cloak for spending cuts.

Turning to the colloquium's second theme, Lucienne Heideman's paper describes an innovative approach to economic development known as Plugging the Leaks. This community-led approach asks communities to liken the local economy to a 'leaky bucket' and to explore ways to stop the leaks. Developed by the New Economics Foundation, the pilot was run by four local authority associations - Sweden, South Africa, Botswana and Namibia - in 24 municipalities in the African partner countries. Lucienne reports the results of the first four Plugging the Leaks workshops in South Africa and Namibia. These identified potential for collective action and networking to promote local growth, but highlighted the need for much better market awareness amongst small-scale entrepreneurs.

Taking up the third theme of environmental sustainability, Tony Jackson and William Lynch explore the ways in which local authorities in Scotland are responding to climate change. Scotland achieved a reduction in greenhouse gas emissions from the mid-1990s to 2007, but evaluations based on production emissions fail to reflect the fact that many goods are manufactured elsewhere. Tony and William argue instead for a focus on consumption emissions, which some Scottish authorities now adopting. Fife Council, for example, has adopted a system for monitoring and controlling its carbon footprint, whilst 
the Highland Council has published a climate-change adaptation plan to counter the impact of sea-water cooling on the economies of coastal regions.

In the first of the three commentaries in this special issue, Olubunmi Ajayi argues for a new emphasis on the role of professionalism in local governments in Africa to combat issues of poverty, inequality and corruption. National policies on professionalism often fail to filter down to local level. African communities need effective local governments which are able to provide democratic leadership, deliver effective services, and empower communities and citizens. However, they face problems associated with compartmentalisation of services, a lack of skills and low pay. Olubunmi argues that these will not be tackled until professionalism becomes embedded in local governments and that this requires the development of professional learning communities that draw on a hybrid of qualifications, on-the-job training and appropriate internal support.

Next, Peter McKinlay examines experience from New Zealand of the potential for shared service provision to cut costs and improve service delivery. He suggests that a lack of expertise combined with political resistance to sharing control with neighbouring authorities have limited the growth of shared services. However, the harsh realities of funding cuts have sparked renewed interest in collaboration. Two examples from New Zealand demonstrate the potential and pitfalls of developing joint council-owned companies. In the Waikato region 13 councils agreed to work together to develop a valuation and ratings database but faced problems of coordination. In the Bay of Plenty the focus was on shared IT and GIS services. Here buy-in at a senior level and the achievement of some 'quick-wins' demonstrated the value of the partnership. Peter argues that this highlights in particular the importance of personal relationships in the development of shared service models.

In their commentary, Brian Dollery, Lin Crase and Bligh Grant argue for adoption of a broad definition of local government sustainability. A narrow focus on financial sustainability in Australia has, they suggest, obscured other important issues. Key performance indicators bear little relationship to financial results so it is important to pay more attention to a range of criteria such as the vibrancy of local democracy, local social capital and local council capacity. Brian and his colleagues believe this could focus attention on the importance of local differences, a sense of community, and pluralist processes which would in turn counter arguments for amalgamation of services. 
Kevin Tayler explores innovations in municipal financing in his review of the new publication on Municipal Infrastructure Financing: Innovative Practices from Developing Countries by Munawwar Alam. Innovations include national development banks and financial institutions, financial intermediaries, municipal bonds, and publicprivate partnerships. All of them require well-managed local government in order to succeed.

Finally, Sue Rhodes (Director of Communications at the Commonwealth Local Government Forum) provides an overview of the proceedings of the CLGF Conference which followed the research colloquium and explored the concept and practice of local economic development from a range of perspectives and different countries. Sue gives details of the key recommendations agreed by delegates in the conference statement the Cardiff Consensus for Local Economic Development. She explains that this statement was subsequently endorsed by the Commonwealth Heads of Government in Perth at the end of October 2011, a move which strengthens the CLGF's attempts to promote actions that enable local government to play its full role in promoting local economic development in a range of countries.

The contributions to this special issue provide a fascinating insight into contemporary challenges facing local governments around the world. The papers presented here and at the research colloquium in March (available at http://www.clgc2011.org/researchcolloquium) confirm the value of research evidence which can inform political debate and policy decisions. They also highlight the continued appetite for discussion among scholars from across the Commonwealth, which augurs well for the future of the journal and research network.

We would like to thank the participants at the colloquium and the authors for their contributions to this special issue and their patience in bearing with a production process which has taken longer than we originally intended. We are very grateful to Gareth Wall for helping to organise the research colloquium and to Lucy Slack at CLGF for her advice and support. We want to put on record our appreciation of the invaluable support given to us by Daniel Grafton and Chris Watterson at University of Technology, Sydney who have taken on the tasks of formatting, proof reading and uploading this issue with patience, skill and good humour. We also acknowledge Daniel's tireless work as 
assistant editor of previous editions of the journal responsible for co-ordinating the production process.

Finally, particular thanks are due to Graham Sansom at UTS who is handing on the editorship of the journal to Alison Brown after several years at the helm. Graham has been the driving force behind the journal and research network and generous in his support and guidance to us as we planned the colloquium and have drawn together the papers for this special issue. He will be a hard act to follow. 